\title{
KEMAMPUAN NABI MUHAMMAD SAW. DALAM MERUBAH LINGKUNGAN MASYARAKAT ARAB JAHILIYAH: TINJAUAN PSIKOLOGI PENDIDIKAN
}

\section{ABILITY OF THE PROPHET MUHAMMAD SAW IN CHANGING THE ENVIRONMENT OF THE ARABIC COMMUNITY OF JAHILIYAH: REVIEW OF EDUCATION PSYCHOLOGY}

\author{
Ahmad Riyadh Maulidi ${ }^{1}$, Muhammad Syukri ${ }^{2}$, Annisa Fadila Mardhatillah ${ }^{3}$ \\ Pascasarjana Pendidikan Agama Islam UIN Antasari Banjarmasin \\ ahmadriyadhmaulidi312@gmail.com
}

\begin{abstract}
According to psychological theory, two forms of interaction between humans and the environment, namely humans can be affected by the environment can be found by humans. The campaign that a good environment will bring good changes for individuals is being carried out. Vice versa, if the environment is bad, then the individuals in that environment are also bad. It is interesting for researchers to see further how the ability of the Prophet Muhammad SAW. in changing the environment of the Arab society of ignorance. Living in the midst of moral decline does not make him affected by the environment. it is the environment that has changed because of his presence. The method used is the library method with a qualitative approach. Psychological theory related to environmental analysis with the ability of the Prophet Muhammad. in changing the Arab environment of ignorance. The results showed that there was a relationship between the psychological perspective on the environment and the ability of the Prophet Muhammad. in changing the Arab environment of ignorance. There are two reasons why the Prophet Muhammad SAW. able to change the Arab environment of ignorance and not be influenced by it, namely because of his status as an Apostle who carries Islamic teachings and noble character who can be an example. It should be in education. Good teaching materials and examples brought by our parents and teachers are a top priority in the educational process today.
\end{abstract}

Keywords: Arab Jahiliyah, Ability, Environment, Psychology

\begin{abstract}
ABSTRAK
Menurut teori psikologi, terdapat dua bentuk interaksi antara manusia dan lingkungan, yaitu manusia dapat terpengaruh oleh lingkungan dan lingkungan dapat dipengaruhi oleh manusia. Kampanye bahwa lingkungan yang baik akan membawa perubahan yang baik bagi individu terus dilakukan. Begitu juga sebaliknya, jika lingkungannya buruk, maka individu yang berada di lingkungan tersebut juga ikut buruk. Hal ini menarik bagi peneliti untuk melihat lebih lanjut bagaimana kemampuan Nabi Muhammad Saw. dalam merubah lingkungan masyarakat Arab jahiliyah. Hidup di tengah kemerosotan akhlak tidak membuat diri beliau terpengaruh terhadap lingkungan tersebut. Justru lingkungan lah yang berubah karena kehadiran beliau. Metode yang digunakan ialah metode kepustakaan dengan pendekatan kualitatif. Teori psikologi yang terkait dengan lingkungan dianalisis dengan kemampuan Nabi Muhammad Saw. dalam merubah lingkungan Arab jahiliyah. Hasil penelitian menunjukkan ada keterkaitan antara perspektif psikologi tentang lingkungan dengan kemampuan Nabi Muhammad Saw.
\end{abstract}


dalam merubah lingkungan Arab jahiliyah. Ada dua sebab mengapa Nabi Muhammad Saw. mampu merubah lingkungan Arab jahiliyah dan tidak terpengaruh olehnya, yakni karena status sebagai Rasul yang membawa ajaran Islam dan akhlak mulia yang dapat menjadi teladan. Begitulah seharusnya dalam pendidikan. materi ajar yang baik dan teladan yang dibawakan oleh orang tua dan guru hendaknya menjadi prioritas utama dalam pencapaian tujuan pendidikan.

Kata Kunci: Arab Jahiliyah, Kemampuan, Lingkungan, Psikologi

\section{PENDAHULUAN}

Nabi Muhammad Saw. adalah sosok manusia yang paling mulia di muka bumi. Selain karena statusnya sebagai seorang Rasul yang menyampaikan risalah Islam, akhlak baik yang beliau miliki membuat kemuliaan itu diakui oleh seluruh umat di dunia. Bahkan pujian tersebut tidak hanya datang dari golongan muslim saja, orang-orang yang membenci beliau pun terbukti kagum dengan sifat dan akhlak yang beliau miliki.

Diutus di tengah-tengah kaum jahiliyah membuat sebuah kisah yang memiliki daya tarik tersendiri bagi pemerhati sejarah maupun bagi kalangan pendidikan. Berbagai penelitian sejarah dan analisa tingkah laku yang dikaitkan dengan kehidupan modern dinilai relevan dalam membentuk suatu pola keteladanan yang dapat diterapkan di masa sekarang. Sehingga kemampuan yang beliau miliki dalam mendidik sebuah masyarakat jahiliyah kala itu menjadi kisah sejarah yang selalu dikenang sampai kapanpun. Nabi Muhammad Saw. diutus di tengah kondisi moral yang sangat memperihatinkan. Segala bentuk penyelewengan dalam ibadah, tindakan zallim dan pengingkaran terhadap kebenaran bahkan perbuatan syirik merupakan perilaku yang selalu dilekatkan pada kondisi Arab Jahiliyah. Sehingga makna "jahil” di sini bukan berarti bodoh dalam hal ilmu pengetahuan, tetapi bodoh dalam artian moral (Sattar, 2017).

Kondisi kehidupan yang jauh dari nilai-nilai moral merupakan ciri khas dari bangsa Arab sebelum Nabi Muhamad Saw. diutus. Penyembahan terhadap berhala, adanya sikap sombong, penindasan, pembentukan kasta ekonomi merupakan sebagian kecil dari bentuk kejahiliyahan bangsa Arab kala itu (Mustaffa, 2020). Sehingga dengan kondisi semacam ini dapat diambil kesimpulan bahwa lingkungan kehidupan Nabi Muhammad Saw. merupakan lingkungan yang tidak baik.

Pembahasan tentang lingkungan dalam membentuk sikap dan perilaku seorang individu merupakan permasalah urgen dalam dunia pendidikan. Menurut teori psikologi 
lingkungan, manusia dan lingkungan akan saling berinteraksi dan saling memengaruhi. Ada dua bentuk interaksi antara manusia dan lingkungan, yaitu: 1) manusia dapat terpengaruh oleh lingkungan dan 2) suatu lingkungan dapat dipengaruhi oleh manusia (Nuqul, 2005). Jika dikaji lebih lanjut, dalam pandangan Barat nampaknya bentuk pertama dari interaksi manusia dan lingkungan ini merupakan bentuk yang identik dengan mazhab behaviorisme dan bentuk yang kedua sangat identik dengan mazhab humanisme. Adapun dalam pandangan Islam, bentuk kedua merupakan bentuk yang identik dengan mazhab psikologi Islam itu sendiri (Yudiani, 2014).

Dewasa ini yang paling banyak dibahas dalam dunia pendidikan sekarang hanyalah bentuk interaksi yang pertama, yakni manusia akan terpengaruh oleh lingkungan sekitarnya. Institusi pendidikan dan siapa saja yang terlibat dalam dunia pendidikan, termasuk orang tua dan guru seolah-olah digiring kepada pemahaman untuk mencari lingkungan sekolah yang baik dan favorit. Sehingga banyak dari mereka berlomba-lomba untuk menyekolahkan anak mereka di sekolah favorit, bergengsi, bahkan mahal (Supriyono \& Jazuli, 2015). Pemikiran seperti ini memang tidak sepenuhnya keliru, namun alangkah lebih baik jika sisi humanisme pada diri seorang anak lebih diutamakan. Bahkan lebih parahnya lagi, kondisi semacam ini akan membuat kasta-kasta sosial dalam dunia pendidikan menjadi semakin Nampak (Ray, 2010). Artinya, tidak hanya lingkungan sekolahnya yang dituntut untuk baik, tetapi bagaimana upaya untuk menciptakan kebaikan tersebut dalam diri seorang anak. Sehingga dari sekolah mana pun ia berasal, ia akan tampil sebagai anak yang telah menempuh pendidikan sesuai dengan tujuan pendidikan yang diharapkan.

Kondisi semacam ini juga sesuai dengan teori yang telah dipaparkan oleh ahli psikologi pendidikan, seperti teori pembelajaran sosial kognitif (cognitive social learning theory) oleh Albert Bandura yang menyatakan bahwa perkembangan seorang individu akan selalu dipengaruhi oleh perilaku, lingkungan dan kemampuan berpikir. Sehingga Bandura berpendapat bahwa lingkungan akan selalu memengaruhi perilaku seseorang (Nurjan, 2020). Bahkan dalam psikologi behaviorisme dikatakan manusia merupakan budak dari lingkungannya. Manusia akan selalu didikte oleh lingkungan, termasuk untuk bertingkah laku (Samad, 2015). Teori semacam inilah yang mendorong para orang tua untuk menyekolahkan anaknya ke sekolah-sekolah favorit. 
Maraknya mazhab behaviorisme yang mengutamakan aspek lingkungan dalam merubah perilaku anak tampak pada penelitian yang dilakukan oleh Sukma dan Widarti. Dalam penelitian tersebut dinyatakan bahwa motivasi mereka untuk menyekolahkan anak mereka ke pondok pesantren dan boarding school ialah agar anak-anak mereka menjadi anak yang saleh dan berilmu pengetahuan, mengingat pondok pesantren dan boarding school mampu menciptakan lingkungan yang baik (Sukma \& Widarti, 2021). Selain itu, menurut sebuah penelitian, lingkungan sekolah ternyata mampu memberikan 41\% sumbangsih terhadap moral siswa. Lingkungan yang baik ini bersumber dari lingkungan fisik dan lingkungan sosial yang tercipta di sekolah (Ardiansyah, Hermuttaqien, \& Wadu, 2019). Dengan kata lain, jika seorang anak bersekolah di lingkungan yang sekolahnya baik, ditambah lagi pendidikan di dalam keluarga yang baik, maka akan mampu menciptakan sosok pribadi yang baik pula.

Penelitian di sini bukan berarti menyalahkan mazhab behaviorisme yang sangat mengutamakan lingkungan. Bukti-bukti yang telah didaparkan di atas menunjukkan bahwa sebuah lignkungan akan memberi pengaruh yang sangat besar terhadap kepribadian seseorang. Penelitian ini merupakan deskripsi untuk mengupas kembali dan membuktikan bagaimana sisi humanisme dari seorang Nabi Muhammad Saw. Hidup di tengah kondisi masyarakat dengan moral yang rendah, ternyata tidak membuat beliau ikut serta dalam kebobrokan lingkungan tersebut. Justru dengan segala kemampuannya, lingkungan bangsa Arab lah yang berubah seiring dengan kehadiran beliau. Begitulah seharusnya pendidikan dilaksanakan. Pendidikan harus dijalankan secara berimbang. Selain menciptakan lingkungan yang baik, pembentukan karakter yang dimulai dari diri seorang anak merupakan komponen penting dalam mencapai tujuan pendidikan yang tidak boleh diabaikan.

\section{METODE PENELITIAN}

Penelitian ini termasuk penelitian deskriptif kualitatif dengan menggunakan metode studi literatur. Berbagai referensi yang terkait dengan psikologi dan kemampuan Nabi Muhammad Saw. dalam merubah lingkungan Arab jahiliyah dianalisis sehingga menghasilkan sebuah kesimpulan. Studi literatur adalah penelitian yang menggunakan 
bahan-bahan kepustakaan sebagai objeknya. Bahan-bahan tersebut dianalisis sesuai dengan tujuan penulisan.

\section{HASIL PENELITIAN}

Kondisi Lingkungan Jahiliyah Sebelum Kelahiran Nabi Muhammad Saw.

Secara geografis, jazirah Arab terdiri dari padang pasir dan tanah subur. Semenanjung Arab terbagi menjadi dua bagian, pertama ialah daerah pedalaman yang kering dan tandus karena jarang dituruni hujan sehingga penduduknya sedikit dan yang kedua ialah daerah pantai di bagian tengah dan selatan. Daerah ini subur karena hujan turun secara teratur. Yang termasuk daerah ini ialah Hijaz, Yaman, Hadramaut, Oman dan Bahrain (Hadrianto, 2016). Hidup di tengah dua imperium besar, yaitu Romawi dan Persia semakin menjadikan bangsa Arab sebagai negeri yang menyedihkan. Kala itu mereka harus takluk pada kekuasaan Romawi atau Persia (Tamimi, Sugandi, \& Wekke, 2018).

Masyarakat yang tinggal di daerah pedalaman disebut dengan penduduk pengelana (ahl al-Badau). Mereka berpindah dari satu tempat ke tempat lain dengan membawa semua harta benda mereka. Ketika menemukan air dan padang rumput, mereka berhenti untuk beristirahat. Pekerjaan utama masyarakat daerah pedalaman ini ialah sebagai peternak unta, domba dan kuda serta berburu. Adapun mereka yang tinggal di daerah pesisir disebut sebagai pemukim (alh al-hadhar). Mereka sudah lebih dulu mengenal pertanian dan kerajinan. Selain itu, penduduk pesisir ini juga berdagang, bahkan dengan orang asing. Sehingga mereka lebih dihormati dari pada orang Arab Badau (Hadrianto, 2016).

Kondisi gurun yang sangat gersang ternyata membawa pengaruh terhadap karakter penduduk Arab. Dengan kondisi alam tersebut, akan melahirkan manusia dengan watak keras (Haikal, 1963). Bangsa Arab diketahui telah memiliki peradaban jauh sebelum datangnya Islam. Peradaban Arab pra Islam sering disebut dengan era jahiliyah (kebodohan). Kebodohan di sini maksudnya ialah ketiadaan pengetahuan mereka dengan agama, tata cara bermasyarakat dan pengetahuan tentang ketuhanan yang Maha Esa. Bahkan tidak hanya jahiliyah, faham barbarisme dan cenderung primitif juga mendominasi kehidupan masyarakat Arab kala itu (Sattar, 2017). 
Sebelum datangnya Islam, mayoritas penduduk jazirah Arab di masa jahiliyah adalah penyembah berhala, sementara minoritas penduduknya beragama Yahudi, Kristen Najran dan Hanif. Sebagian besar mereka tersebar di daerah Yastrib, Arab Selatan dan Makkah. Setiap suku mempunyai berhala masing-masing. Jenis dan bentuknya bervariasi, tergantung pada pandangan mereka tentang tuhannya. Berhala-berhala tersebut kemudian diletakkan di Kakbah. Sehingga fungsi Kakbah yang dulunya sebagai tempat peribadatan bagi agama Hanif, kini berubah menjadi tempat pemujaan berhalaberhala mereka (Nasution, 2013).

Ada beberapa kebiasaan buruk yang melekat pada kehidupan Arab pra Islam, seperti gemar berperang, angkuh dan sombong, mabuk-mabukkan dan berjudi serta memiliki sifat yang kejam. Hidup di jazirah Arab yang gersang dan tandus tentu memerlukan tambahan sumber dalam rangka menunjang kehidupan. Selain itu, binatang ternak yang mereka gembala pun memerlukan ladang-ladang. Sehingga mereka harus menyebrang menuju perkampungan orang lain. Kampung yang menjadi tujuan tersebut ternyata juga mengalami masalah yang sama, sehingga untuk memperebutkan sumber kehidupan dan lading untuk hewan ternak ditempuh dengan cara berperang. Siapa yang kuat dialah yang berhak untuk hidup. Kala itu peperangan dijadikan sebagai sarana untuk mempertahankan hidup. Selain itu, latar belakang terjadinya perang ini dikarenakan bangsa Arab dikenal hidup dengan kabilah. Mereka hidup berdampingan antar kabilah dengan perjanjian damai yang disebut al-Ahlaf. Sistem kabilah ini ternyata memunculkan fanatisme di antara mereka. Kecintaan terhadap keluarga, garis keturunan dan suku mengalahkan kecintaan mereka terhadap hal lainnya. Tidak jarang fanatisme ini memunculkan perkelahian yang berakhir dengan peperangan (Muzhiat, 2019).

Adapun yang kedua ialah angkuh dan sombong. Darah di kalangan masyarakat Arab mempunyai harga yang sangat tinggi. Setiap darah yang tertumpah dari salah satu anggota sukunya menjadi kewajiban bagi seluruh anggota suku untuk menuntut balas tanpa melihat apa yang menjadi penyebabnya. Hal ini merupakan akibat dari sifat angkuh dan sombong yang mereka miliki. Mereka merasa menjadi orang yang paling hebat di antara yang lainnya (Nasution, 2013).

Kebiasaan buruk yang ketiga ialah pemabuk dan penjudi. Kebiasaan ini dilakukan oleh semua kalangan, baik yang kaya maupun kalangan bawah. Kalangan masyarakat 
Arab yang kaya menganggap minuman keras dan berjudi sebagai barang mewah dan kebiasaan orang kaya. Dengan pekerjaan tersebut mereka mampu memamerkan kekayaannya. Sedangkan bagi kalangan ekonomi lemah, mabuk-mabukan dan judi merupakan tempat pelarian untuk melupakan himpitan hidup yang berat (Nasution, 2013).

Kebiasaan buruk selanjutnya ialah kejam. Kondisi dan kedudukan wanita pada saat itu hanya dipandang sebelah mata. Wanita dianggap sebagai manusia tidak ada harganya dan tidak lebih berharga dari barang dagangan di pasar. Apabila seorang ayah diberi tahu bahwa anaknya yang lahir adalah seorang wanita, dia sedih bercampur marah. Bahkan bayi wanita tersebut dikubur hidup-hidup. Alasan penguburan tersebut dikarenakan bahwa wanita merupakan penyebab kemiskinan dan aib bagi keluarga. Kehidupan yang keras dan menantang mendorong mereka untuk memiliki anak laki-laki. Kekejaman tersebut juga terlihat dari sistem perkawinan. Ada tiga macam jenis perkawinan yang pernah dipraktekkan oleh Arab jahiliyah, yaitu 1) istibdha, artinya ialah seorang suami meminta kepada istrinya untuk berjimak dengan lelaki lain yang dipandang mulia, 2) maqthu', artinya ialah kebolehan seorang laki-laki untuk menikahi ibu tirinya setelah ayahnya meninggal dunia dan 3) badal, yakni tukar menukar istri tanpa perceraian dengan tujuan memuaskan hawa nafsu (Supriyadi, 2008).

Kebiasaan tersebut merupakan kebiasaan terburuk yang pernah terjadi. Walaupun ada karakter positif bangsa Arab kala itu, seperti pemberani, memiliki fisik dan daya ingat yang kuat dan kesadaran akan harga diri dan martabat, namun ketika karakter positif tersebut tidak tersentuh oleh nilai religius, maka keburukan pun tetap akan menyertainya (Hadrianto, 2016). Sebelum itu, para rasul diutus dengan bingkai kesuksesan yang teratur. Tetapi, selama 600 tahun tidak ada seorang Rasul pun yang diutus ke bumi. Hingga hadirlah Nabi Muhammad Saw. dengan segala mukjizat, kemampuan dan akhlaknya untuk merubah lingkungan tersebut menuju lingkungan yang berperadaban.

\section{Lingkungan dalam Perspektif Psikologi}

Lingkungan merupakan tempat manusia saling berinteraksi dan saling memengaruhi. Lingkungan dalam bahasa Inggris disebut dengan environment adalah situasi yang dapat memengaruhi perilaku seseorang (Rapoport, 1990). Situasi tersebut 
bisa berupa situasi sosial ataupun situasi fisik. Selain itu, antara lingkungan dengan manusia juga saling memengaruhi. Sehingga dapat dikatakan bahwa terdapat hubungan timbal balik antara lingkungan dan manusia (Muslih, 2015).

Menurut teori psikologi, lingkungan memegang peranan yang sangat penting, lingkungan akan memberi pengaruh terhadap perilaku manusia. Lingkungan yang baik akan membawa manusia ke perilaku yang baik, sebaliknya lingkungan yang buruk akan membawa manusia ke perilaku yang buruk. Nuqul menjelaskan bahwa manusia dan lingkungan akan saling berinteraksi dan saling memengaruhi. Manusia dapat terpengaruh oleh lingkungan dan tidak menutup kemungkinan jika lingkungan tersebut dapat dipengaruhi oleh manusia. Ada tiga cara bagaimana lingkungan dapat memengaruhi manusia, yaitu: 1) lingkungan akan mengundang dan mendatangkan perilaku. 2) lingkungan akan membentuk diri. 3) lingkungan akan memengaruhi cintra diri (Nuqul, 2005).

Ada beberapa tokoh yang menjelaskan lingkungan menurut psikologi. Pertama, menurut John Locke (dalam Saleh, 2018), lingkungan memiliki peranan penting dalam membentuk tingkah laku seseorang. Teori ini disebut dengan teori "tabularasa", yaitu manusia lahir tidak memiliki pembawaan apapun, adapun tingkah laku ditentukan oleh lingkungan. Kedua, menurut Sartain (dalam Purwanto, 2000) lingkungan adalah meliputi semua kondisi dan cara tertentu dalam memengaruhi tingkah laku, pertumbuhan, dan perkembangan. Ketiga, menurut Mohammad Surya, lingkungan ialah segala sesuatu yang dapat merangsang manusia, sehingga manusia ikut terlibat dan memengaruhi perkembangannya (Surya, 2014).

Adapun menurut Piaget (dalam Hendrowati, 2015) menyatakan bahwa seorang individu mempunyai kemampuan untuk membentuk pengetahuan. Hal ini dikarenakan individu tersebut melakukan interaksi yang terus menerus dengan lingkungannya. Piaget meyakini bahwa pengalaman-pengalaman fisik sebagai hasil dari interaksi dengan lingkungan merupakan hal penting terhadap perkembangan seorang individu. Walaupun titik tekan Piaget berada pada keaktifan siswa dalam proses pembentukan pengetahuan tersebut, namun bukan berarti hal ini menjadikan lingkungan sebagai suatu yang terabaikan. Ketika lingkungan yang ia hadapi merupakan lingkungan yang baik, kemudian ditambah keaktifan seorang individu dalam berinteraksi dengan lingkungan 
tersebut, maka terbentuklah pengetahuan yang baik pula. Lingkungan tersebut dapat berupa lingkungan keluarga, sekolah dan masyarakat.

Keberhasilan dalam pendidikan keluarga akan menjadi jalan pembuka dalam keberhasilan pendidikan sekolah dan masyarakat. Orang tua menjadi pendidik serta contoh pertama bagi anak-anak mereka. Ketika penanaman karakter yang dilakukan oleh orang tua berjalan dengan baik, maka karakter anak yang berada dalam keluarga tersebut pun akan baik (Khaerani, 2020).

Menurut Ni'matuzahroh dan Prasetyaningrum (2018), pola asuh yang diterapkan oleh orang tua sangat memengaruhi proses perkembangan anak. Orang tua dituntut untuk sabar, ulet dan sungguh-sungguh agar mampu mengarahkan anak mereka kepada pribadi yang baik dan sukses. Hal ini dikarenakan lingkungan keluarga merupakan lingkungan peletak dasar dalam mengembangkan kemampuan fisik, kognitif, bahasa, sosial, kemandirian, moral, bahkan nilai-nilai agama pada anak.

Dalam sebuah penelitian, terdapat 210 anak yang dijadikan sampel ketika melihat pengaruh pola asuh yang diberikan oleh orang tua terhadap kemandirian anak. Hasil penelitian ini menyebutkan ternyata 185 dari 210 anak tersebut sudah mampu melakukan segala sesuatu dengan mandiri. Ternyata hal ini disebabkan pola asuh berupa pengajaran yang diberikan oleh orang tua. Jika di rumah seorang anak selalu dibimbing dan dibiasakan kemudian diajarkan melakukan sesuatu, maka ia akan menjadi anak yang mandiri. Lingkungan yang membawa ia kepada sifat mandiri ini juga dapat dilakukan melalui ucapan. Jika lingkungan keluarganya selalu menganggap ia bodoh, maka seorang anak akan terus menganggap dirinya seperti itu. Kondisi ini menyebabkan anak cenderung kurang percaya diri (Ni'matuzahroh \& Prasetyaningrum, 2018).

Lingkungan yang kedua ialah lingkungan sekolah. Lingkungan sekolah dalam tinjauan psikologi merupakan bahasan bagaimana sebuah lingkungan yang ada di sekolah berpengaruh terhadap perubahan tingkah laku peserta didik. Apakah lingkungan yang ada di sekolah, baik fisik maupun sosial akan berpengaruh terhadap tingkah laku peserta didik. Menurut Ayeni dan Adelabu (dalam Rahayu \& Sutama, 2015) menyatakan bahwa kondisi gedung, tata kelola kelas, fasilitas di dalam kelas dan nilai estetika ruangan kelas akan berpengaruh terhadap kualitas belajar mengajar. Kondisi gedung, tata kelas dan fasilitas serta nilai estetika yang baik akan membawa pengaruh positif terhadap 
kualitas belajar mengajar. Begitu juga sebaliknya. Hal ini dikarenakan rasa semangat yang ada dalam diri peserta didik akan meningkat jika dihadapkan dengan kondisi ruangan yang nyaman. Sehingga perilaku giat belajar pun akan meningkat.

Lingkungan yang ketiga ialah lingkungan masyarakat. Kata masyarakat diambil dari bahasa Arab yaitu syirkah atau syarika yang berarti persekutuan, perkumpulan atau perserikatan. Dari sini dapat diartikan bahwa masyarakat merupakan kumpulan perseorangan yang mempunyai keyakinan dan tujuan yang sama, menghimpun diri secara harmmonis dengan maksud dan tujuan bersama (Suhada, 2017). Lingkungan ini nantinya akan memberi pengaruh terhadap tingkah laku seseorang yang ikut serta dalam lingkungan tersebut.

Lingkungan masyarakat merupakan faktor eksternal yang sangat berpengaruh terhadap hasil belajar siswa. Lingkungan masyarakat yang penuh dengan tuntutan para siswa akan membuat ia aktif, sehingga akan berpengaruh positif terhadap hasil belajarnya. Lingkungan masyarakat yang berisi dengan kegiatan kemasyarakatan akan mendorong seorang anak menjadi lebih percaya diri dan mampu beradaptasi dengan orang sekitarnya. Sehingga pada nantinya prestasi belajarnya pun akan meningkat (Hermawan, Suherti, \& Gumilar, 2020).

Analisis Kemampuan Nabi Muhammad Saw. dalam Merubah Lingkungan Arab Jahiliyah: Tinjauan Psikologi

Pada pembahasan di atas telah disinggung bahwa dalam pandangan Barat bentuk kedua dari interaksi antara manusia dan lingkungan, yakni suatu lingkungan dapat dipengaruhi oleh manusia merupakan bentuk yang dekat dengan mazhab humanisme. Keterkaitan tersebut dilihat dalam sudut pandang bahwa mazhab humanisme merupakan aliran psikologi yang cenderung melihat kebutuhan dan nilai-nilai manusia (Vasuhi, 2011). Mazhab humanisme berpandangan bahwa mansia terlahir dengan citra dan atribut yang baik, seperti punya pemikiran, imajinas, rasa tanggung jawab, nilai seni, dan kemampuan dalam menentukan kehidupan (Yudiani, 2014). Adapun dalam pandangan Islam, ketika manusia dapat memengaruhi suatu lingkungan, artinya ia punya kemampuan yang serba baik, tidak seperti mazhab humanisme yang cenderung melupakan Tuhan. Dalam pandangan Islam manusia merupakan makhluk yang 
membawa potensi baik (fitrah), mempunyai dua unsur yakni jasmani dan ruhanis serta mempunyai pusat tingkah laku yang disebut dengan kalbu. Dari sini dapat difahami bahwa bentuk kedua dalam pandangan Islam sangat dekat dengan aliran psikologi Islam.

Kekuatan manusia seperti yang diyakini oleh mazhab humanisme dan mazhab psikologi Islam inilah yang mampu mempengaruhi lingkungan. Apapun lingkungan yang menyertainya maka akan mampu diubah oleh manusia dengan kekuatan baik yang dibawanya tersebut. Seburuk apapun lingkungan di sekitarnya, ia tidak akan terpengaruh. Justru si manusia itulah yang berhasil merubahnya. Hal ini terlihat dari kemampuan Nabi Muhammad Saw. dalam merubah kondisi masyarakat Arab yang dulunya dikenal sebagai masyarakat dengan kerendahan moral kemudian menjadi masyarakat madani yang dikenal di seluruh dunia. Bahkan menurut Nasution dalam Syaifudin menyatakan bahwa kemajuan bangsa Barat pada mulanya bersumber dari peradaban Islam yang masuk ke Eropa melalui Spanyol (Syaifudin, 2018). Kemampuan Nabi Muhammad Saw. ini terlihat berbeda dengan teori John Locke (dalam Saleh, 2018), Sartain (dalam Purwanto, 2000), dan Mohammad Surya (2014). Jika mereka berpandangan bahwa lingkungan akan berperan dalam membentuk dan memengaruhi tingkah laku, pertumbuhan dan perkembangan seseorang, maka Nabi Muhammad Saw. justru tidak terpengaruh bahkan lingkungan tadi lah yang mengikuti dan terpengaruh dengan risalah dan akhlak mulia yang beliau tampilkan.

Setidaknya ada dua sebab yang menjadi latar belakang mampunya Nabi Muhammad Saw. dalam merubah lingkungan sekitar (masyarakat Arab) menurut perspektif psikologi, baik humanisme maupun psikologi Islam. Sebab tersebut ialah karena status Nabi Muhammad Saw. sebagai utusan Allah Swt. dan karena akhlak mulia yang beliau miliki. Sebagai utusan Allah Swt. yang terakhir, tentu beban dan tanggung jawab yang diemban Nabi Muhammad Saw. sangatlah berat. Menyiarkan Islam sebagai agama yang rahmatan lil 'alamin memerlukan sebuah strategi dan petunjuk dari Allah Swt. Kemampuan beliau dalam merubah sifat dan perilaku masyarakat Arab selain dikarenakan akhlak mulia beliau, juga disebabkan karena risalah yang dibawa merupakan sesuatu yang dapat merubah masyarakat, yakni ajaran agama Islam.

Dalam mazhab humanistik, seorang guru mempunyai peran yang sangat besar. Selain karena ia merupakan manusia yang berusaha mengarahkan kemampuan 
muridnya dengan maksimal (Aliakbari, Parvin, Heidari, \& Haghani, 2015), guru juga berperan sebagai fasilitator yang aktif dalam pembelajaran. Guru membantu menciptakan iklim kelas yang kondusif, memperjelas tujuan belajar, mendorong peserta didik untuk semangat dalam belajar, menyediakan fasilitas dan menerima pertanyaan dan pendapat dari peserta didik (Nast \& Yarni, 2019). Tentu peran seperti ini juga dimiliki oleh Nabi Muhammad Saw. sebagai utusan Allah Swt. Dalam psikologi Islam, manusia merupakan makhluk yang terlahir dalam keadaan suci (fitrah). Fitrah ini merupakan potensi yang dimiliki manusia untuk melakukan tindakan yang benar dan cenderung tunduk kepada Allah Swt (Al Afify, 2018). Dengan adanya fitrah inilah, maka Nabi Muhammad Saw. melakukan dakwah agar potensi baik tersebut dapat menduduki peran penting dalam diri manusia yang selama ini diabaikan oleh masyarakat Arab Jahiliyah.

Potensi yang baik tentu akan memberi kemudahan dalam dakwah Nabi Muhammad Saw. Tabiat dasar dan potensi yang dimiliki oleh manusia tersebut akan senantiasa memotivasi seseorang untuk melakukan kebajikan melalui perantara ilmu, akal dan kesadarannya. Bahkan konsepsi fitrah tersebut menurut Ridla dalam Taufiq tidak perlu diajarkan kembali sebab manusia lahir dalam keadaan fitrah (Taufiq, 2016). Itulah mengapa tokoh Quraisy yang sangat membenci Nabi Muhammad Saw. sekalipun masih memiliki kekaguman terhadap kemuliaan yang dipancarkan dari diri Nabi Muhammad Saw. Karena bagaimanapun juga manusia akan selalu menyukai hal-hal baik sesuai dengan fitrah yang ia bawa sejak lahir. Pernah diceritakan suatu ketika di hari peperangan Badar, Akhnas bin Suraiq berjumpa dengan Abu Jahal, ia berkata, "Wahai Abal Hakam! (Abu Jahal), di sini tidak ada orang selain engkau dan aku yang mendengar apa yang kita bicarakan. Hendaknya engkau memberitahukan kepadaku tentang keadaan Muhammad yang sebenarnya. Apakah ia (Muhammad) termasuk seorang yang benar atau seorang pendusta?". Abu Jahal pun dengan tegasnya menjawab, "Demi Allah, sesungguhnya Muhammad itu adalah orang yang benar dan beliau tidak pernah berdusta sekalipun" (Chalil, 2001).

Kondisi yang demikian membuat lingkungan jahiliyah kala itu mampu dirubah oleh Nabi Muhammad Saw. Dengan modal yakin bahwa manusia terlahir dengan segala kemampuan dan fitrahnya, maka ajaran baik yang disampaikan dan ditambah dengan 
keteladanan akan memberi keberhasilan tersendiri dalam pencapaian tujuan dakwah Islam. Begitu juga peran seorang guru di hadapan peserta didik. Ia harus tampil dengan segala keyakinan bahwa hakikat peserta didik merupakan sosok manusia dengan potensi yang siap untuk dididik dan dikembangkan. Sehingga guru bahkan peserta didik nantinya akan lahir sebagai individu yang siap pula dalam merubah lingkungan sekitarnya. Hal ini sesuai dengan teori psikologi lingkungan yang menyatakan bahwa manusia punya kemampuan untuk merubah lingkungannya (Nuqul, 2005).

Materi ajar juga berperan penting dalam kajian psikologi pendidikan. Dalam tinjauan mazhab humanistik, seorang guru tidak bisa memaksan materi yang tidak disukai dan tidak relevan dengan kehidupan peserta didik. Materi yang disajikan harus sesuai dengan hakikat dan fungsi serta peran manusia itu sendiri (Nast \& Yarni, 2019). Proses dakwah Nabi Muhammad Saw. sebagai utusan Allah Swt. untuk merubah kondisi lingkungan masyarakat Arab jahiliyah, tentu juga membawa sebuah materi ajar yang disebut dengan risalah atau ajaran Islam. Ajaran Islam yang diturunkan kepada Nabi Muhammad Saw. ini tentunya sangat sesuai dengan hakikat dan fungsi serta peran manusia sebagai penerima risalah tersebut. Jika manusia diberi potensi yang baik dan menyukai kebaikan, tentu risalah yang dibawa pun juga mengarahkan manusia kepada nilai-nilai kebaikan (Muiz, 2014). Selain risalah yang dibawa, pola penyampaian risalah tersebut pun juga sesuai dengan sifat dan tabiat manusia.

Menurut teori belajar kognitif Piaget, sebuah proses pembelajaran akan berhasil jika menyesuaikan dengan tahap perkembangan kognitif peserta didik. Tahap tersebut dimulai sejak bayi baru lahir hingga dewasa. Tahap tersebut ialah tahap sensorimotor, tahap praoperasional, tahap operasi konkrit dan tahap operasi formal (Widyati, 2014). Dengan memperhatikan tahapan ini, maka tingkat keberhasilan belajar peserta didik akan semakin besar. Begitu juga ketika risalah Islam disampaikan oleh Nabi Muhammad Saw. Adanya tahapan pembebanan hukum (al-Tadarruj al-Tasyri') membuat hukum syariat yang disampaikan oleh Nabi Muhammad Saw. mudah diterima masyarakat Arab kala itu. Hal ini terlihat dari adanya tahapan dalam hukum pengharaman meminum khamr. Tahap pertama ialah dengan cara membandingkan antara rezeki yang baik dan khamr (Q.S. an-Nahl: 79), Tahap kedua ialah dengan menyatakan bahwa khamr mengandung lebih banyak dosa daripada manfaatnya (Q.S. al-Baqarah: 219). Tahap 
ketiga ialah larangan meminum khamr ketika ingin melaksanakan salat (Q.S. an-Nisa: 43) dan tahap keempat ialah finalisasi dari pengharaman minum khmar tersebut (Q.S. alMaidah: 96). Dengan adanya tahapan ini, maka hukum pengharaman meminum khamr tersebut mudah diterima. Sebab, tradisi minuman keras masyarakat Jahiliyah sebelum turun ayat-ayat tersebut sudah mendarah daging dalam kehidupan mereka (Amin, 2014). Sehingga dengan metode ini, Nabi Muhammad Saw. mampu merubah bahkan menghilangkan tradisi minum khamr tersebut karena tidak sesuai dengan ajaran Islam.

Adapun sebab kedua yang menjadi latar belakang mampunya Nabi Muhammad Saw. dalam merubah lingkungan sekitar (masyarakat Arab jahiliyah) ialah karena akhlak mulia yang ada pada diri beliau. Dalam teori psikologi, perbincangan masalah moral merupakan hal yang urgen. Sebab dengan moral inilah yang akan dapat mengantarkan seorang individu pada diterimanya dalam kelompok sosial di sekitarnya. Menurut Hurlock dalam Daulay menyatakan bahwa pendidikan moral pada anak merupakan proses yang panjang dan lama. Sehingga diperlukan konsistensi dan strategi yang tepat dalam hal tersebut. Cara dalam pembentukan moral ini ialah melalui proses modeling (teladan) dan reinforcement (penguatan). Melalui keteladanan ini, maka dalam teori Albert Bandura seorang anak akan menampilkan dan mengadopsi perilaku orang lain untuk diterapkan pada dirinya (Daulay, 2015). Dari pemaparan ini dapat dipahami bahwa keteladanan dan sikap baik orang tua maupun guru sangat penting dalam pembentukan karakter anak. Untuk mengembangkan pribadi anak ke arah yang lebih baik diperlukan sosok orang tua dan guru yang dapat menjadi teladan bagi anak. Dengan demikian, proses pendidikan moral akan berjalan dengan semestinya.

Konsep keteladanan inilah yang sudah jauh sebelumnya dilakukan oleh Nabi Muhammad Saw. dalam mendakwahkan Islam. Dengan menampilkan keteladanan dan perilaku yang baik, maka siapa saja yang menerima dakwah Rasulullah Saw. akan dengan ikhlas berbondong-bondong masuk ke dalam agama Islam (Arsyad, 2017). Sehingga dengan keteladanan tersebut, lingkungan Arab yang dahulunya kering dengan nilai-nilai moral, menjadi tanah yang dikenal dan disegani oleh dunia luar karena sifat dan akhlak mulia yang dicontoh dari Nabi Muhammad Saw.

Ada beberapa keteladana yang telah dicontohkan oleh Nabi kepada para penduduk Arab, seperti bersikap jujur, sabar, tidak sombong, dan peka terhadap lingkungan serta 
suka menolong. Sikap jujur merupakan sikap yang paling terkenal dalam diri Nabi Muhammad Saw. Karena sifat jujurnya inilah Nabi Muhammad Saw. diberi gelar oleh penduduk kota Makkah dengan gelar al-Amin atau orang yang dapat dipercaya. Kejujuran Nabi Muhammad Saw. sudah terlihat sejak beliau berusia 12 tahun saat berdagang. Saat itu beliau sudah mengunjungi beberapa negara, seperti Syam, Ethiopia, Yordania, Yaman dan Bagdad. Cara berdagang yang jujur dan tidak merugikan orang lain inilah yang membuat barang yang dijual Rasululah Saw. akan selalu laris. Ketika berdagang beliau tidak pernah melanggar janji terkait kesepakatan perdagangan, tidak pernah menutupi kecacatan terhadap barang yang dijual dan beliau juga tidak pernah sekalipun mengurangi timbangan (Markas, 2014).

Adapun dalam hal sabar, beliau merupakan sosok utusan Allah Swt. yang punya misi dakwah. Dalam berdakwah, berbagai tantangan dan rintangan merupakan hal yang sering dilalui beliau. Dari diusir ke luar kampung halaman, dijauhkan dari keluarganya, para kerabatanya diboikot, sahabat-sahabatnya disiksa dan pengikut-pengikutnya dibunuh selalu beliau hadapi dengan penuh kesabaran. Berbagai hinaan, cacian dan lemparan batu dan kotoran sudah menjadi hal biasa bagi Nabi Muhammad Saw. saat itu. Bahkan suatu ketika Uqbah bin Abu Mu'ith pernah meletakkan kotoran unta di pundak beliau. Tidak hanya kotoran unta, Ubay bin Khalaf juga pernah meludahi dan melempari beliau dengan remukkan tulang unta. Selain itu, suatu hari tatkala Nabi Muhammad Saw. sedang berjalan menuju Ka'bah untuk menunaikan salat, tiba-tiba ada seorang laki-laki dari kafir Quraisy yang meludahi muka beliau. Ajaibnya, beliau membalas ludahan tersebut dengan senyum sembari membersihkan ludah tersebut. Kejadian it uterus berulang hingga berkali-kali. Namun Nabi Muhammad Saw. tidak pernah marah dan tidak pernah membalasnya. Suatu ketika Rasulullah Saw. heran, sebab di suatu hari tidak ada lagi yang meludahinya. Beliau pun menanyakan keberadaan laki-laki tersebut kepada tetangganya, ternyata laki-laki yang sering meludahi beliau tadi dalam kondisi sakit. Bukannya senang melihat laki-laki tersebut dalam kondisi sakit, justru Rasulullah Saw. menjenguknya dan mendoakan kesembuhannya (Syarbini \& Haryadi, 2010).

Sifat ketiga yang menjadi nilai teladan dalam diri Rasulullah Saw. ialah perilaku tawadhu' (tidak sombong). Nabi Muhammad Saw. merupakan pribadi yang tidak pernah meremehkan orang lain. Ketawadhu'an beliau ditunjukkan kepada para sahabat. Suatu 
ketika saat nabi datang sekumpulan sahabat ada yang membawa tongkat. Para sahabat kemudian berdiri untuk menghormati kedatangan beliau. Melihat hal tersebut dengan muka agak marah, Nabi Muhammad Saw. pun bersabda, "Janganlah tuan-tuan berdiri seperti orang-orang asing berdiri, yang mana sebagian yang lain memuliakan yang lainnya." Begitu juga saat di majelis, beliau tidak pernah memilih tempat duduk dan tidak berdiri sebelum majelis itu selesai. Setiap orang yang duduk bersama beliau akan merasa dimuliakan oleh beliau (Rahmawati, 2016).

Sifat selanjutnya dalam diri Rasulullah Saw. ialah peka terhadap lingkungan dan suka menolong. Perilaku suka menolong merupakan realisasi dari kepekaan terhadap lingkungan. Sebagai pemimpin agama dan negara, Nabi Muhammad Saw. selalu hadir sebagai sosok yang gemar menolong. Kepekaan dan kepeduliannya dengan orang sekitar membuat dercak kagum baik kalangan Islam maupun luar Islam. Suatu hari ada seorang hamba sahaya mendatangi Rasulullah Saw. Ia agak memaksa untuk mengajak baginda nabi pergi ke suatu tempat untuk menyelesaikan urusan pribadinya. Tanpa banyak tanya, Rasulullah Saw. langsung ikut bersama hamba sahaya tersebut. Nabi Saw. mengantar dan menungguinya hingga ia selesai dengan urusannya (Maghfira, 2017).

Keteladanan yang dimiliki oleh Rasulullah Saw. inilah yang menjadi daya tarik tersendiri bagi penduduk Arab kala itu. Menyampaikan risalah Islam yang syarat dengan nilai-nilai kebaikan, dengan pola penyampaian yang disesuaikan dengan fitrah dan kemampuan manusia dan ditambah dengan keteladanan sikap dan perilaku terpuji tentu menjadikan masyarakat Arab mudah dalam menerima Islam. Secara bertahap kekeringan nilai moral tersebut dapat dirubah. Hingga akhirnya lingkungan Arab sebagai lingkungan sekitar kehidupan Nabi Muhammad Saw. mampu dirubah oleh Nabi Muhammad Saw. menjadi lingkungan yang maju dan berperadaban.

\section{KESIMPULAN DAN SARAN}

Menurut psikologi, lingkungan akan memberi pengaruh kepada manusia. Jika suatu lingkungan baik, maka akan memberi pengaruh yang baik pula terhadap individu yang ada di dalamnya. Jika lingkungan tersebut buruk, maka pengaruh buruk akan didapatkan oleh siapa saja yang berada dalam lingkungan tersebut. Dilahirkannya Nabi Muhammad Saw. di tengah lingkungan Arab jahiliyah yang buruk tidak membuat perilaku Nabi Muhammad Saw. berubah menjadi buruk. Justru lingkungan itulah yang berhasil beliau 
rubah. Terdapat keterkaitan antara perspektif psikologi khususnya dalam ranah pendidikan dengan kemampuan Nabi Muhammad Saw. dalam merubah lingkungan Arab jahiliyah. Ada dua hal yang menjadi alasan mampunya Nabi Muhammad Saw. dalam merubah lingkungan Arab jahiliyah, yaitu karena status sebagai beliau Rasul yang membawa ajaran Islam dan akhlak mulia yang dapat menjadi teladan. Begitulah seharusnya dunia pendidikan berjalan. Materi ajar yang baik dan teladan yang dibawakan oleh orang tua dan guru hendaknya menjadi prioritas utama dalam menunjang proses pendidikan di masa sekarang. Sehingga tujuan pendidikan dapat tercapai dengan maksimal.

\section{DAFTAR PUSTAKA}

Al Afify, M. F. (2018). Konsep Fitrah dalam Psikologi Islam. Tsaqafah: Jurnal Peradaban Islam, 14(2), 280.

Aliakbari, F., Parvin, N., Heidari, M., \& Haghani, F. (2015). Learning Theories Application in Nursing Education. Journal of Education and Health Promotion, 4(2), 9.

Amin, A. R. M. (2014). Prinsip dan Fenomena Moderasi Islam dalam Tradisi Hukum Islam. Qalam: Jurnal Penelitian Agama Dan Sosial Budaya, 20(3), 31.

Ardiansyah, H., Hermuttaqien, B. P. F., \& Wadu, L. B. (2019). No TitlePengaruh Lingkungan Sekolah Terhadap Moral Siswa Sekolah Menengah Pertama. Jurnal Moral Kemasyarakatan, 4(1), 5.

Arsyad, J. (2017). Metode Keteladanan dalam Perspektif Sirah Nabawiyah. Tazkiya: Jurnal Pendidikan Islam, 6(2), 21.

Chalil, M. (2001). Kelengkapan Tarikh Nabi Muhammad Saw. Jakarta: Gema Insani Press.

Daulay, N. (2015). Pendidikan Karakter pada Anak dalam Pendekatan Islam dan Psikologi. Miqot: Jurnal Ilmu-Ilmu Keislaman, 39(1), 210-211.

Hadrianto, N. (2016). Sosiologi Dalam Sastra Arab Jahiliah: Pendekatan Sosiologis dalam Karya Puisi An-Nabighoh Adz-Dzubyani. Tsaqofah Dan Tarikh: Jurnal Kebudayaan Dan Sejarah Islam, 1(1), 104.

Haikal, M. H. (1963). Hayatu Muhammad. Kairo: Maktabah al-Nahdhah al-Misriyah.

Hendrowati, T. Y. (2015). Pembentukan Pengetahuan Lingkaran Melalui Pembelajaran Asimilasi dan Akomodasi Teori Konstruktivisme Piaget. Jurnal E-DuMath, 1(1), 2-3.

Hermawan, Y., Suherti, H., \& Gumilar, R. (2020). Pengaruh Lingkungan Keluarga, Lingkungan Kampus, Lingkungan Masyarakat Terhadap Prestasi Belajar Mahasiswa. Jurnal Edukasi, 8(1), 56.

Khaerani. (2020). Pendidikan Karakter pada Generasi Milenial. In Dunia Pendidikan Indonesia: Menuju Era Revolusi 4.0 (p. 62). Maluku: AA Rizky.

Maghfira, B. (2017). 101 Akhlak Nabi Muhammad Saw. Jakarta: Cerdas Interaktif.

Markas. (2014). Urgensi Sifat Jujur dalam Berbisnis. Jurnal Pilar, 2(2), 164-175.

Muiz, M. M. (2014). Menjadi Muslim Profesional Sesuai Alquran. Jakarta: Elex Media Komputindo.

Muslih, M. (2015). Pengaruh Lingkungan Keluarga dan Lingkungan Sekolah Terhadap 
Prestasi Belajar Siswa Kelas 6 SDN Limbangan. Syntax Literate: Jurnal Ilmiah Indonesia, 1(4), 41-42.

Mustaffa, N. N. M. (2020). Perubahan Tingkah Laku Masyarakat Arab Jahiliyyah kepada Tingkah Laku Beragama. Jurnal Pengajian Islam, 13(1), 21-22.

Muzhiat, A. (2019). Historiografi Arab Pra Islam. Tsaqofah: Jurnal Agama Dan Budaya, 17(2), 133.

Nast, T. P. J., \& Yarni, N. (2019). Teori Belajar Menurut Aliran Psikologi Humanistik dan Implikasinya dalam Pembelajaran. Jurnal Review Pendidikan Pengajaran, 2(2), 272.

Nasution, S. (2013). Sejarah Peradaban Islam. Pekanbaru: Yayasan Pustaka Riau.

Ni'matuzahroh, \& Prasetyaningrum, S. (2018). Observasi: Teori dan Aplikasi dalam Psikologi. Malang: Universitas Muhammadiyah Malang.

Nuqul, F. L. (2005). Pengaruh Lingkungan Terhadap Perilaku Manusia: Studi Terhadap Perilaku Penonton Bioskop. Psikoislamika: Jurnal Psikologi Dan Psikologi Islam, 2(1), 2.

Nurjan, S. (2020). Kecenderungan Perilaku Delinkuensi Remaha. In Dinamika Psikologi Pendidikan Islam (p. 181). Ponorogo: Wade Group.

Purwanto, M. N. (2000). Psikologi Pendidikan. Bandung: Remaja Rosdakarya.

Rahayu, S. M., \& Sutama. (2015). Pengelolaan Sarana dan Sarana Pendidikan Sekolah Menengah Pertama. Jurnal Varidika: Kajian Penelitian Pendidikan, 27(2), 126.

Rahmawati, S. (2016). Gambar Ketawadu'an Nabi Muhammad Saw. dalam Al-Qur'an. UIN Alauddin Makassar.

Rapoport, A. (1990). The Meaning of the Built Environment:A Nonverbal Communication Approach. Tucson: University of Arizona Press.

Ray, D. (2010). Sociology, Social Class and Education. In The Routledge International Hnadbook of the Sociology of Education (p. 397). USA and Canada: Routledge.

Saleh, A. A. (2018). Pengantar Psikologi. Makassar: Aksara Timur.

Samad, S. A. A. (2015). Konsep Ruh dalam Perspektif Psikologi Pendidikan Barat dan Islam. Fenomena: Jurnal Penelitian, 7(2), 223.

Sattar, A. (2017). Respons Nabi Terhadap Tradisi Jahiliyyah: Studi Reportase Hadis Nabi. Jurnal Theologia, 28(1), 184.

Suhada. (2017). Lingkungan Pendidikan dalam Perspektif Al Qur'an. Jurnal Hikmah, $13(1), 16$.

Sukma, R., \& Widarti. (2021). Motivasi Orang Tua Memilih Pondok Pesantren Insan Cendekia Boarding School Payakumbuh. An-Nuha: Jurnal Pendidikan Agama Islam, 1(2), 4.

Supriyadi, D. (2008). Sejarah Peradaban Islam. Bandung: Pustaka Setia.

Supriyono, \& Jazuli, A. (2015). Aplikasi Sistem Informasi Sekolah (SIS) untuk Pengelolaan Sekolah di Kabupaten Kudus. Prosiding SNATIF, 323.

Surya, M. (2014). Psikologi Guru: Konsep dan Aplikasinya. Bandung: Alfabeta.

Syaifudin, M. (2018). Nilai-nilai Pendidikan Islam dalam Sejarah Muhammad Al Fatih sebagai Penakluk Konstantinope. Institut Agama Islam Negeri Salatiga.

Syarbini, A., \& Haryadi, J. (2010). Dahsyatnya Sabar, Syukur dan Ikhlas Muhammad Saw. Bandung: Ruang Kata.

Tamimi, R. H., Sugandi, B., \& Wekke, I. S. (2018). Muhammad Saw. dan Peletakan Dasar Peradaban Islam. Jurnal Aqlam: Journal of Islam and Plurality, 3(1), 21.

Taufiq, I. (2016). Al-Quran Bukan Kitab Teror: Membangun Perdamaian Berbasis Al-Quran. 
Yogyakarta: Bentang Pustaka.

Vasuhi, R. (2011). Humanism: A Human Perspective in English Language Teaching. International Seminar on Humanistic Language and Literature Teaching, 1. Chennai: Anna University.

Widyati, W. (2014). Belajar dan Pembelajaran Perspektif Teori Kognitivisme. Jurnal Biology Science and Education, 3(2), 179.

Yudiani, E. (2014). Komparasi Paradigma Psikologi Kontemporer Versus Psikologi Islam Tentang Manusia. Jurnal Ilmu Agama: Mengkaji Doktrin, Pemikiran, Dan Fenomena Agama, 15(1), 14-18. 